\title{
Human neoplastic B cells express more than two isotypes of immunoglobulins without deletion of heavy-chain constant-region genes
}

\author{
Tatsuo Kinashi, Tore Godal, ${ }^{1}$ Yoshihiko Noma, Noel R. Ling, ${ }^{2}$ Yoshio Yaoita, and Tasuku Honjo \\ Department of Medical Chemistry, Kyoto University Faculty of Medicine, Kyoto 606, Japan; 'Laboratory for Immunology, \\ The Norwegian Radium Hospital, Oslo, Norway; ${ }^{2}$ Department of Immunology, The Medical School, The University of \\ Birmingham, Birmingham, UK
}

\begin{abstract}
Flow cytometric analyses of surface immunoglobulins of human neoplastic $B$ cells from four patients indicated that more than two isotypes were expressed on the surface of each patient's neoplastic B cells. Southern blot analysis of DNAs of these cells showed that each patient's neoplastic cells had the monoclonal rearrangement profile of the $J$ segment of the immunoglobulin heavy-chain gene. Heavy-chain constant-region genes of these cells had no deletion associated with $S-S$ recombination. Northern blot analysis of RNA from two neoplastic cells revealed that each RNA contained comparable amounts of mRNAs for two different isotypes which were identified by surface staining. These results support the hypothesis that the simultaneous expression of two different isotypes in a certain stage of B-cell differentiation is mediated by alternative RNA splicing without DNA deletion.
\end{abstract}

[Key Words: Immunoglobulin class switch; alternative splicing; Northern blot analysis; Southern blot analysis; flow cytometry]

Received February 9, 1987; revised version accepted April 24, 1987

During differentiation of B lymphocytes (B cells), IgM is the first antibody expressed on the cell surface. IgG- and IgA-secreting cells are the descendants of cells that initially expressed IgM. Since the assembled variable $(V)$ gene segments do not change in a lineage of the B cells, the switch of immunoglobulin class does not alter the antigen specificity of the antibody. Molecular mechanisms to replace the expressed constant region $(C)$ of the immunoglobulin heavy-chain $(H)$ without affecting the $V$ region have been suggested to involve deletion of $C_{\mathrm{H}}$ genes $5^{\prime}$ to the expressed $C_{\mathrm{H}}$ gene either by intrachromatid or sister chromatid recombination (Honjo and Kataoka 1978; Cory and Adams 1980; Rabbitts et al. 1980; Yaoita and Honjo $1980 \mathrm{a}, \mathrm{b})$. Since deletion of $C_{\mathrm{H}}$ genes is mediated by recombination between the switch (S) regions located $5^{\prime}$ to each $C_{\mathrm{H}}$ gene, except for the $C_{\delta}$ gene, this rearrangement is referred to as $\mathrm{S}-\mathrm{S}$ recombination (Kataoka et al. 1980). The switch regions are composed of tandem arrays of short repetitive sequences (Kataoka et al. 1981; Nikaido et al. 1981).

B cells expressing two isotypes such as IgM and IgG have often been reported during normal B-cell development. The simultaneous expression of two immunoglobulin classes is difficult to explain by a deletion model. Yaoita et al. (1982) reported that there were no $C_{\mathrm{H}}$ gene deletions in $\mu^{+} \epsilon^{+} \mathrm{B}$ lymphocytes sorted from spleens of hookworm (Nippostrongylus brasiliensis)-injected SIA $/ 9$ mice whereas $I_{\mathrm{H}}$ loci were rearranged. The results imply that the simultaneous expression of the $C_{\mu}$ and $C_{\epsilon}$ genes may be mediated by differential RNA splicing of an mRNA precursor containing a single $V_{\mathbf{H}}$ and multiple $C_{\mathrm{H}}$ region sequences. On the basis of this experiment we have proposed a two-step model for class switching (Yaoita et al. 1982). The first step involves synthesis of a long primary transcript including a $V_{\mathrm{H}}$ and multiple $C_{\mathrm{H}}$ genes, and its differential RNA splicing. In the second step the intervening DNA sequence is deleted by $\mathrm{S}-\mathrm{S}$ recombination. Subsequently, several other groups reported experiments in support of (Perlmutter and Gilbert 1984; Chen et al. 1986) and against (Katona et al. 1985) this model. However, the recent report that B cells of SJA/9 mice lack $F_{\epsilon}$ receptors (Adachi et al. 1985) does not agree with the claim that $\mu^{+} \epsilon^{+} B$ cells of hookworm-injected SJA/9 mice are due to cytophilic association of IgE (Katona et al. 1985).

In this study we will describe the organization and expression of $J_{\mathrm{H}}$ and $C_{\mathrm{H}}$ genes of human neoplastic $B$ cells from four patients that express more than two isotypes on their surface. Expression of mRNA of two isotypes and the absence of the $C_{\mathrm{H}}$ gene deletion in these leukemic cells support the model proposed previously (Yaoita et al. 1982). 
Table 1. Profile of surface immunoglobulins of neoplastic cells

\begin{tabular}{|c|c|c|c|c|c|c|c|c|}
\hline \multirow{2}{*}{$\begin{array}{l}\text { Neoplastic } \\
\text { cells }\end{array}$} & \multirow{2}{*}{$\begin{array}{l}\text { Pheno- } \\
\text { types }\end{array}$} & \multicolumn{7}{|c|}{$\begin{array}{l}\text { Percentages of cells } \\
\text { expressing immunoglobulins }\end{array}$} \\
\hline & & anti-Ig & $\mu$ & $\delta$ & $\gamma$ & $\alpha$ & $\kappa$ & $\lambda$ \\
\hline & & 89 & 85 & 30 & 1 & 41 & 3 & 85 \\
\hline $268 / 85$ & $\mu \delta \gamma / \lambda$ & $\mathrm{ND}^{a}$ & 39 & 60 & 56 & 1 & 2 & 82 \\
\hline $302 / 78$ & $\mu \delta \gamma / \kappa$ & 87 & 83 & 25 & 75 & $<1$ & 78 & \\
\hline Ll61 & $\delta \alpha / \kappa$ & 92 & $<1$ & 85 & $<1$ & 60 & 95 & $<1$ \\
\hline
\end{tabular}

Cells were stained with class-specific and anti-human immunoglobulin (anti-Ig) antibodies and positive cells were counted by flow cytometry. Neoplastic cells are chronic leukemia cells, except in the case of $145 / 85$ cells, which are malignant lymphoma cells. Numbers represent percentages of cells stained by FITC-labeled isotype-specific antisera (Dalso, Copenhagen, Denmark).

a (ND) Not determined.

\section{Results and discussion}

\section{Characterization of surface immunoglobulins of} leukemic cells by flow cytometry

Peripheral blood leukocytes were isolated from patients (three Norwegian and one British) with chronic lymphocytic leukemia or lymphoma of B-cell origin. We analyzed their surface immunoglobulins by flow cytometry. As shown in Table 1, about $90 \%$ of these cells were surface immunoglobulin-positive with a predominant light-chain isotype. They were stained with antibodies (monoclonal or affinity-purified) specific to each class. Interestingly enough, the additive ratios of positive cells stained with antibodies against different isotypes exceeded 1. This result indicates the presence of cells expressing more than two classes of immunoglobulins simultaneously. All the specimens expressed predominantly either $\kappa$ or $\lambda$ light chain. The $145 / 85$ cells seem to express the $\delta$ - or $\alpha$-chain in addition to the $\mu$-chain. About half of the 268/85 cells expressed only one of the $\mu-, \delta-$, and $\gamma$-chains, indicating that a significant portion of $268 / 85$ cells carried more than two isotypes. The major populations of the $302 / 78$ and L161 cells were $\mu^{+} \gamma^{+}$and $\delta^{+} \alpha^{+}$, respectively. A significant portion of the $302 / 78$ cells also expressed the $\delta$-chain.

\section{Monoclonal origins of the neoplastic cells}

We investigated the profile of the $I_{\mathrm{H}}$ segment rearrangement and deletion of immunoglobulin $C_{\mathrm{H}}$ genes in the neoplastic cells of the four patients. High-molecularweight DNAs extracted from the peripheral blood cells of the patients were digested with EcoRI, BamHI, and HindIII. DNA fragments were electrophoresed and transferred to nitrocellulose filters, which were hybridized with DNA probes to test the rearrangement of the immunoglobulin loci. Figure 1 shows the probes and restriction enzyme cleavage sites of the human immunoglobulin loci.

Any rearrangements in the $I_{\mathrm{H}}$ locus involving $V_{\mathrm{H}}-\mathrm{D}-$ $J_{\mathrm{H}}$ joining would alter the size of EcoRI, BamHI, and HindIII fragments hybridized with the $J_{\mathrm{H}}$ probe ( $\mathrm{a}$ in Fig. 1). Since the rearrangement profile of the $J_{\mathrm{H}}$ segment is unique to each lymphocyte, examination of the $I_{\mathrm{H}}$ rearrangement of each patient's cells provides a direct test for the clonality of neoplastic cells as well as extent of contamination by non-B cells. As shown in Figure 2 (lanes 1 and 4), all the DNA preparations contained one or two rearranged $J_{\mathrm{H}}$ segments, indicating that the majority of all the patients' cells were monoclonally expanded B cells. DNAs of the 145/85 (Fig. 2A), 268/85 (Fig. 2B), and L161 (Fig. 2D) cells had two rearranged $J_{\mathrm{H}}$ segments and a faint germ line $J_{\mathrm{H}}$ segment. The results show that both alleles of the $J_{\mathrm{H}}$ segments are rearranged. Furthermore, the contamination by non-B cells was negligible for the present analyses. DNA of the $302 / 78$ cells contained one germ line and one rearranged $J_{\mathrm{H}}$ band. The intensity of the germ line $J_{\mathrm{H}}$ band was less than the rearranged band, probably because of the longer size of the fragment. The results also indicate that the contamination with other cells was not significant.

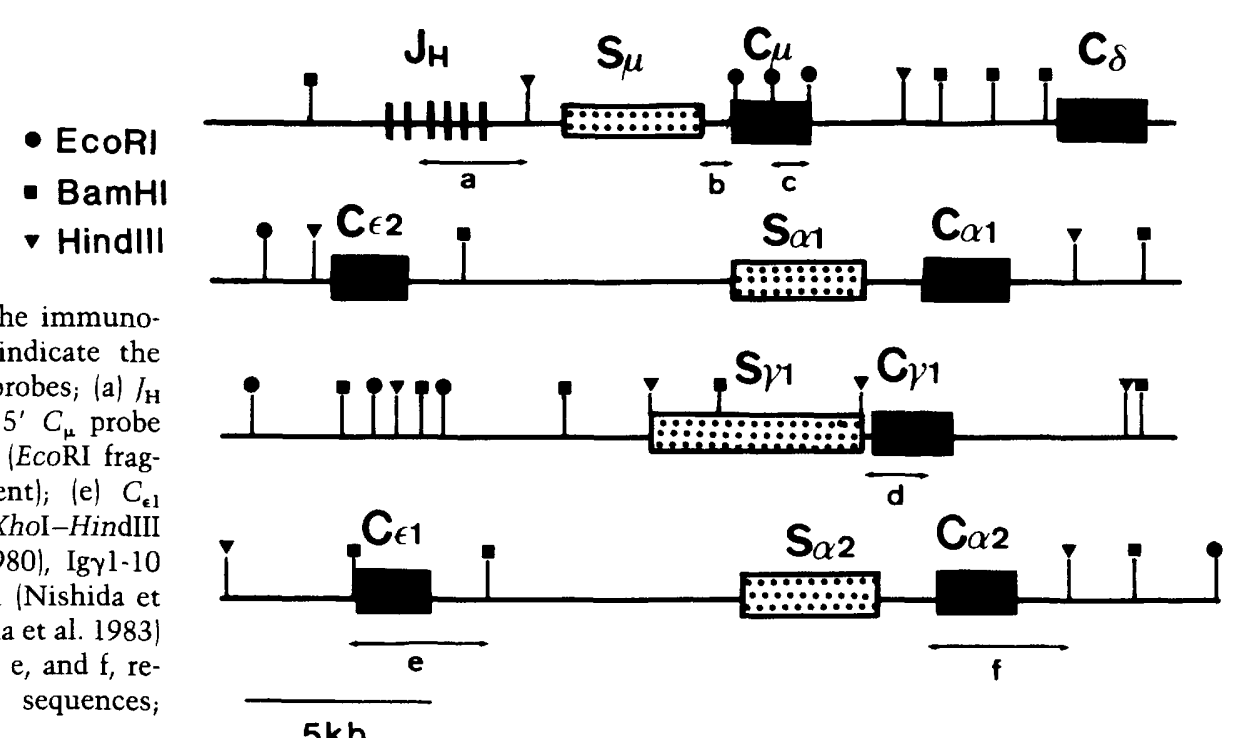

Figure 1. The restriction maps of the immunoglobulin locus. Horizontal arrows indicate the DNA fragments that were used as probes; $(\mathrm{a}) /_{\mathrm{H}}$ probe (EcoRI-HindIII fragment); (b) $5^{\prime} C_{\mu}$ probe (SacI-EcoRI fragment); (c) $C_{\mu}$ probe (EcoRI fragment); (d) $C_{\gamma 1}$ probe (SacII fragment); (e) $C_{\epsilon 1}$ (BamHI fragment); (f) $C_{\alpha 1}$ probe (XhoI-HindIII fragment). H24 (Takahashi et al. 1980), Ig $\gamma 1-10$ (Takahashi et al. 1982), CH4A·H·Igel (Nishida et al. 1982), and CH4A.H.Ig 25 (Hisajama et al. 1983) are original clones for probes $a-c, d, e$, and $f$, respectively. (Closed box) Structural sequences; (dotted box) S regions.

$5 \mathrm{~kb}$ 
A

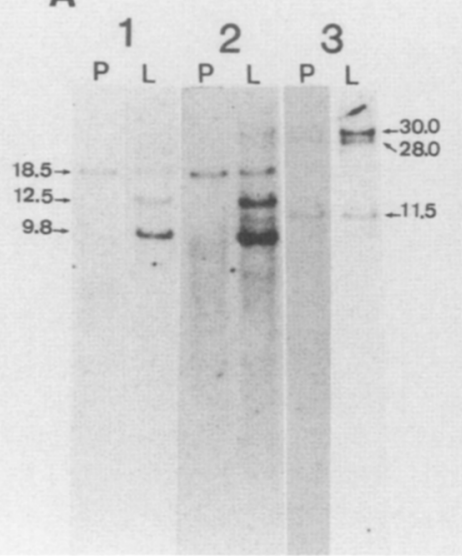

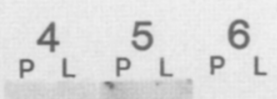

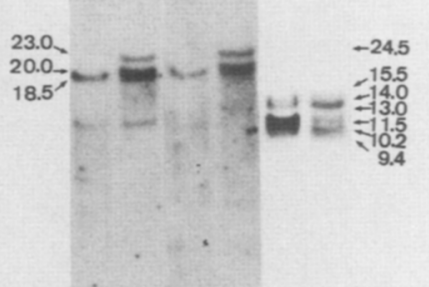

B
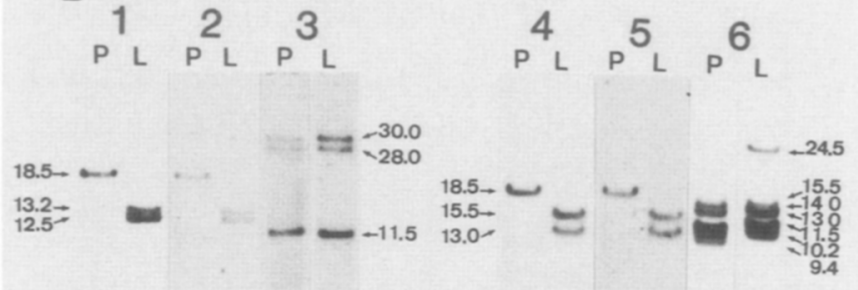
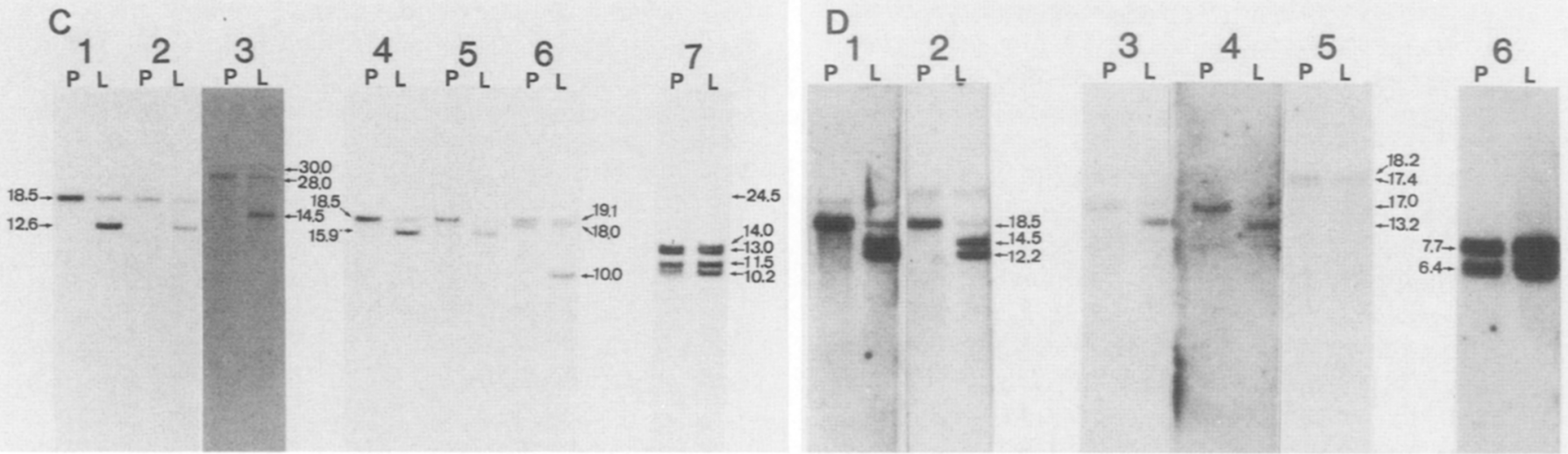

Figure 2. Southern blot analyses of neoplastic cells. Each lane is a pair of patient DNA (L) and human placental DNA (P). $(A) 145 / 85$ cell DNA was digested with EcoRI (lanes 1-3) or BamHI (lanes 4-6). Probes used are: $I_{\mathrm{H}}$ probe for lanes 1 and 4, $5^{\prime} C_{\mu}$ probe for lanes 2 and 5 , and $C_{\alpha 2}$ probe for lanes 3 , and $C_{\gamma 1}$ probe for lane $6 .(B)$ 268/85 cell DNA was digested with EcoRI (lanes 1-3) or digested DNA, $B a m H I$ (lanes 4-6). Probe used are: $J_{\mathrm{H}}$ probe for lanes 1 and $4,5^{\prime} C_{\mu}$ probe for lanes 2 and $5, C_{\epsilon 1}$ probe for lane 3 , and $C_{\gamma 1}$ probe for lane 6. (C) 302/78 cell DNA was digested with EcoRI (lanes 1-3) or BamHI (lanes 4-7). Probes used are: $J_{\mathrm{H}}$ probe for lanes 1 and $4 ; 5^{\prime} C_{\mu}$ probe for lanes 2 and $5 ; C_{\alpha 2}$ probe for lanes 3 and 6 ; and $C_{\gamma 1}$ probe for lane 7. $(D)$ L161 cell DNA was digested with $E c 0$ RI (lanes 1 and 2), BamHI (lanes 3-5), or HindiII (lane 6). Probes used are $J_{\mathrm{H}}$ probe for lanes 1 and $3 ; 5^{\prime} C_{\mu}$ probe for lanes 2 and $4 ; C_{\alpha 2}$ probe for lane 5 ; and $C_{\gamma 1}$ probe for lane 6 .

\section{Absence of recombination in the $\mathrm{S} \mu$ region}

To assess whether or not the neoplastic cells underwent S-S recombination involving rearrangements in the $S_{\mu}$ region located between the $J_{\mathrm{H}}$ and $C_{\mu}$ genes, we used the $5^{\prime} C_{\mu}$ probe (b in Fig. 1) which contains the immediate $5^{\prime}$ - flanking region of the $C_{\mu}$ gene. Both the $J_{\mathrm{H}}$ and $5^{\prime} C_{\mu}$ probes should hybridize with the same EcoRI or BamHI fragment as long as the $J_{\mathrm{H}}$ and $C_{\mu}$ sequences are physically linked. In the $145 / 85$ cells, the $5^{\prime} C_{\mu}$ probe hybridized with two rearranged fragments (12.5- and 9.8-kb EcoRI fragments, and 23- and 20-kb BamHI fragments) that are identical to those detected by the $J_{\mathrm{H}}$ probe, indicating that the $I_{\mathrm{H}}$ and $C_{\mu}$ genes were physically linked in the 145/85 cells (Fig. 2A, lanes 2 and 5). In the 268/85 cells $J_{\mathrm{H}}$ loci of both alleles rearranged to give rise to two new fragments, namely $13.2-\mathrm{kb}$ and $12.5-\mathrm{kb} E c o$ RI fragments and $15.5-\mathrm{kb}$ and $13-\mathrm{kb}$ BamHI fragments. These rearranged $I_{\mathrm{H}}$ bands were physically linked with the $C_{\mu}$ gene as the EcoRI and BamHI fragments of the same sizes were hybridized with the $5^{\prime} C_{\mu}$ probe (Fig. 2B, lanes 2 and 5). The $302 / 78$ cells contained one rearranged $I_{\mathrm{H}}$ fragment which was physically linked with the $C_{\mu}$ gene because the rearranged bands (12.6-kb EcoRI and $15.9-\mathrm{kb}$ BamHI fragments) hybridized with the $C_{\mu}$ and $J_{\mathrm{H}}$ probes were superimposable (Fig. 2C, lanes 2 and 5). In the L161 cells, the sizes of two rearranged $J_{\mathrm{H}}$ fragments were identical to those hybridized with the $5^{\prime} C_{\mu}$ probe (Fig. 2D, lanes 2 and 4), again indicating that the $J_{\mathrm{H}}$ and the $C_{\mu}$ genes are physically linked on both alleles of the L161 cells.

\section{Absence of $\mathrm{C}_{\mathrm{H}}$ gene deletion}

We further investigated the genomic contexts of other $C_{\mathrm{H}}$ genes in the four neoplastic cells. The human $C_{\mathrm{H}}$ genes are clustered on chromosome 14 in the order of $5^{\prime}-C_{\mu}-C_{\delta}-C_{\gamma 3^{-}}-C_{\gamma 1}-C_{\epsilon 2^{-}}-C_{\alpha 1^{-}}-\psi C_{\gamma^{-}} C_{\gamma 2^{-}} C_{\gamma 4^{-}} C_{\epsilon 1}-C_{\alpha 2^{-}} 3^{\prime}$ (Flanagan and Rabbitt 1982; Bech-Hansen et al. 1983). The 
$C_{\epsilon 1}$ probe (e in Fig. 1) cross-hybridizes with the $C_{\epsilon 2}$ and $C_{\epsilon 3}$ genes, and the $C_{\alpha 2}$ probe (f in Fig. 1) cross-hybridizes with the $C_{\alpha 1}$ gene. In addition, the $C_{\epsilon 1}$ probe detects a third fragment containing the $C_{\epsilon 3}$ gene which is located on chromosome 9 (Max et al. 1982). Since each pair of the $C_{\epsilon}$ and $C_{\alpha}$ genes $\left(C_{\epsilon 2}-C_{\alpha 1}\right.$ and $\left.C_{\epsilon 1}-C_{\alpha 2}\right)$ is located on a single EcoRI fragment ( $30 \mathrm{~kb}$ and $28 \mathrm{~kb}$, respectively) (Max et al. 1982; Nishida et al. 1982), both $C_{\mathbf{\epsilon} 1}$ and $C_{\alpha 2}$ probes (e and $f$ in Fig. 1, respectively) hybridize to the two identical EcoRI fragments (30 and $28 \mathrm{~kb})$ in the human germ line DNA. All $C_{\epsilon}$ and $C_{\alpha}$ genes in the four neoplastic cells were in the germ line context (lane 3 in $A$ and B, lanes 3 and 6 in $C$, and lane 5 in D of Fig. 2), excluding deletion of the $C_{\epsilon}$ and $C_{\alpha}$ genes.

In the $302 / 78$ cells one additional band $(14.5-\mathrm{kb}$ EcoRI or $10-\mathrm{kb}$ BamHI band) appeared when hybridized with the $C_{\alpha 2}$ probe. However, the possibility that this fragment was created by $S_{\mu}-S_{\alpha}$ recombination and linked with the $J_{\mathrm{H}}$ segment was excluded because the sizes of the EcoRI and BamHI fragments hybridized with the $C_{\alpha 2}$ probe were different from those hybridized with the $J_{\mathrm{H}}$ and $5^{\prime} C_{\mu}$ probes. Since the 30-kb EcoRI for 19.1-kb $B a m H I)$ band of $302 / 78$ DNA was fainter than those of placental DNA, we considered that the $14.5-\mathrm{kb}$ EcoRI for $10-\mathrm{kb} \mathrm{BamHI}$ ) fragment of the $302 / 78$ cells originated by polymorphic deletion somewhere around the $C_{\alpha 1}$ gene on one allele of $302 / 78$ cells.

The $C_{\gamma 1}$ probe (d in Fig. 1) which cross-hybridized with all the subclasses of the $C_{\gamma}$ genes revealed that the $C_{\gamma}$ genes of the neoplastic cells were also in the germ line context (lane 6 in A, B, and D, and lane 7 in Fig. 2C). Two polymorphic counterparts of the $\left.15.5-\mathrm{kb} \mid C_{\gamma 2}\right)$ and 9.4-kb $\left(C_{\gamma_{4}}\right)$ bands in human placental DNA (Takahashi et al. 1982; Noma et al. 1984) were not seen in the 268/85 cells. The results indicate that the $C_{\gamma}, C_{\boldsymbol{\epsilon}}$ and $C_{\alpha}$ genes were not deleted from the four neoplastic cells.

\section{Presence of $m R N A s$ for two isotypes}

We analyzed transcripts of immunoglobulin genes in the $145 / 85$ and $268 / 85$ cells because the transcripts are more abundant in these cells than in the other cells. Total RNA extracted from the 145/85 leukemic cells contained $2.4-\mathrm{kb}$ and $2.1-\mathrm{kb} \mu$-chain mRNA, which encodes the membrane-bound and secretory forms of the $\mu$ chain, respectively, as shown in Figure 3A. The 145/85 RNA also contained 1.9-kb mRNA for the membranebound form of the $\alpha$-chain. The amount of the $C_{\alpha}$ transcripts was about one-half of that of the $C_{\mu}$ transcripts, judging from intensities of the bands.

The 268/85 cells contained $2.4-\mathrm{kb}$ and $2.1-\mathrm{kb} \mu$-chain mRNAs, and $3.0-\mathrm{kb}$ (membrane-bound form) and $1.7-\mathrm{kb}$ (secretory form) $\gamma$-chain mRNAs (Fig. 3B). The $\gamma$-chain mRNA bands were rather broad because of partial degradation of RNA as identified by ethidium bromide staining. $\alpha$-Chain mRNA was not detected in the $268 / 85$ cells, even after long exposure (data not shown). The amount of the $C_{\gamma}$ gene transcripts was estimated to be about one-half of the $C_{\mu}$ gene transcripts by densitometric tracing.

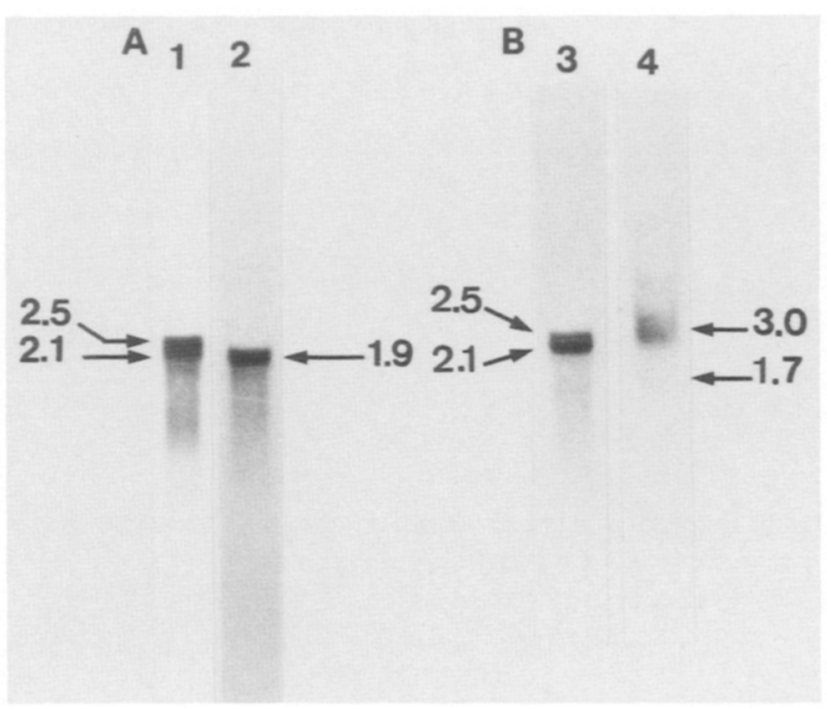

Figure 3. Presence of $C_{\mu}, C_{\gamma}$ and $C_{\alpha}$ mRNAs in neoplastic cells. Total RNAs $(10 \mu \mathrm{g}$ each) of $145 / 85 \mid A)$ and $268 / 85(B)$ cells were electrophoresed in agarose gels, blotted onto filters, and hybridized with the $C_{\mu}$ (lanes 1 and 3), $C_{\alpha 2}$ (lane 2), and $C_{\gamma 1}$ (lane 4) probes. Filters were autoradiographed for $30 \mathrm{~min}$ (lanes 1 and 2), 1 hr (lane 3), and $2 \mathrm{hr}$ (lane 4).

\section{Differential splicing model}

The results of DNA and mRNA analyses are summarized in Table 2. All four cases contained one or two rearranged $J_{\mathrm{H}}$ segments, but no evidence for $\mathrm{S}-\mathrm{S}$ recombination was found in $C_{\mathrm{H}}$ region genes. In two of the four cases the class and the amount of the heavy-chain mRNA correlated with those of the surface immunoglobulin was determined by flow cytometry.

These results could be explained by a mixture of leukemic cells expressing IgM and contaminant non-neoplastic lymphocytes expressing other classes of immunoglobulins or by a mixture of two populations of leukemic cells, each expressing different immunoglobulin classes on their surface. These possiblilities are, however, unlikely because most of the peripheral leukocytes of these patients were monoclonal cells on the basis of surface marker studies and the profiles of $/_{\mathrm{H}}$ rearrangement.

The most plausible explanation for these results is that the neoplastic cells express different classes of immunoglobulins simultaneously by alternative RNA splicing of a long primary transcript as proposed by Yaoita et al. (1982). The two-step model for class switching assumes that a long transcript including a $V_{\mathrm{H}}-D-J_{\mathrm{H}}$ complex and various $C_{\mathrm{H}}$ gene sequences is synthesized and its alternative splicing gives rise to mRNAs with the same $V_{\mathbf{H}}-D-J_{\mathbf{H}}$ and different $C_{\mathbf{H}}$ sequences. Since the long transcript may be $180 \mathrm{~kb}$ long in order to express $\operatorname{IgM}$ and $\operatorname{IgA}$, it is impossible to analyze it by gel electrophoresis. Because the amounts of RNAs were limited, we could not demonstrate that different classes of immunoglobulin had the same $V_{\mathrm{H}}-D-J_{\mathrm{H}}$ complex. We considered that these neoplastic cells derived 
Table 2. Summary of organization of the immunoglobulin $\mathrm{C}_{H}$ genes and their expression in human leukemic cells

\begin{tabular}{|c|c|c|c|c|c|c|c|}
\hline \multirow{2}{*}{$\begin{array}{l}\text { Neoplastic } \\
\text { cells }\end{array}$} & \multirow[b]{2}{*}{ Phenotype } & \multirow[b]{2}{*}{$J_{\mathrm{H}^{\mathrm{a}}}$} & \multirow{2}{*}{$\begin{array}{l}\text { Linkage of } \\
I_{\mathrm{H}^{-}} C_{\mu}\end{array}$} & \multicolumn{3}{|c|}{$C_{\mathbf{H}}$ genes $^{\mathbf{a}}$} & \multirow[b]{2}{*}{ mRNA } \\
\hline & & & & $C_{\gamma}$ & $C_{\alpha}$ & $C_{\epsilon}$ & \\
\hline $145 / 85$ & $\mu \delta \alpha / \lambda$ & $\mathrm{R} / \mathrm{R}$ & $+1+$ & $\mathrm{G} / \mathrm{G}$ & $\mathrm{G} / \mathrm{G}$ & $\mathrm{G} / \mathrm{G}$ & $\mu^{+} \alpha^{+}$ \\
\hline $268 / 85$ & $\mu \delta \gamma / \lambda$ & $\mathrm{R} / \mathrm{R}$ & $+1+$ & $\mathrm{G} / \mathrm{G}$ & $\mathrm{G} / \mathrm{G}$ & $\mathrm{G} / \mathrm{G}$ & $\mu^{+} \gamma^{+}$ \\
\hline $302 / 78$ & $\mu \delta \gamma / \kappa$ & $\mathrm{R} / \mathrm{G}$ & $+1+$ & $\mathrm{G} / \mathrm{G}$ & $\mathrm{R} * / \mathrm{G}$ & $\mathrm{G} / \mathrm{G}$ & $\mathrm{ND}^{\mathrm{b}}$ \\
\hline Ll61 & $\delta \alpha / \kappa$ & $\mathrm{R} / \mathrm{R}$ & $+1+$ & $\mathrm{G} / \mathrm{G}$ & $\mathrm{G} / \mathrm{G}$ & $\mathrm{G} / \mathrm{G}$ & ND \\
\hline
\end{tabular}

Rearrangement at $J_{\mathrm{H}}$ loci and $C_{\mathrm{H}}$ genes, and $/_{\mathrm{H}}-C_{\mu}$ linkage were investigated.

a $(R)$ Rearranged; $(G)$ germ line; $(R / G$ and $R / R)$ rearrangement in one and both alleles, respectively; $\left(R^{*}\right)$ rearrangement is due to the deletion somewhere around the $C_{\alpha 1}$ gene on one allele (see the text).

$b$ (ND) Not determined because of scarce supply of the cells.

from transformation of double producers that existed at a certain stage during differentiation of B cells.

Perlmutter and Gilbert (1984) also demonstrated different $C_{\mathrm{H}}$ sequences in a single transcript by sandwich RNA hybridization. More recently, Chen et al. (1986) showed that a variant of a murine B-cell leukemic line $\mathrm{BCL}_{1} 2.58$ produced the $\mu$ - and $\gamma$-chain mRNA as well as the two isotypes. $\mathrm{BCL}_{1} 2.58$ contained a single rearranged $I_{\mathrm{H}}$ segment. Taken together, these observations suggest that double producers exist and that these cells produce different classes of the immunoglobulin by alternative splicing during differentiation, possibly before $S-S$ recombination.

\section{Materials and methods}

\section{FACS analysis}

Mononuclear cells from the blood of patients with chronic lymphatic leukemia or from lymphoid tissues in the case of lymphoma were stained with antibodies against the $\lambda_{-}, \kappa_{-}^{-}, \mu-, \gamma_{-}$, and $\alpha$-chains. Cells were analyzed further by flow cytometry (FACS). We have collected multi-isotype-bearing specimens (other than or in addition to $\mu$ and $\delta$ ), in which the total number of cells stained with antibodies against heavy chains exceeded that of cells stained with anti- $\lambda$ and anti- $\kappa$ antibodies (see Table 1).

\section{DNA isolation and Southern hybridization}

High-molecular-weight DNA from peripheral mononuclear cells was extracted as described (Yaoita and Honjo 1984). Approximately $1-2 \mu \mathrm{g}$ of DNA was digested with appropriate restriction enzymes, electrophoresed in $0.5 \%$ agarose gels, and transferred to nitrocellulose filters by the method of Southern (1975). Hybridization to nick-translated ${ }^{32}$ P-labeled probes was carried out for $18 \mathrm{hr}$ in $1 \mathrm{M} \mathrm{NaCl}$ at $65^{\circ} \mathrm{C}$. Filters were washed in $0.015 \mathrm{M} \mathrm{NaCl}, 1.5 \mathrm{mM}$ sodium citrate, $0.1 \%$ SDS and exposed to Kodak XRP films at $-80^{\circ} \mathrm{C}$ with an intensifying screen.

\section{Northern blot hybridization}

Total RNA was prepared by homogenization of cells in guanidium thiocyanate and subsequent centrifugation on a $\mathrm{CsCl}$ cushion (Ullrich et al. 1977). Approximately $10 \mu \mathrm{g}$ of total RNA was treated with glyoxal and dimethylsulfoxide, fractionated by electrophoresis in agarose gels containing $10 \mathrm{~mm}$ sodium phos-

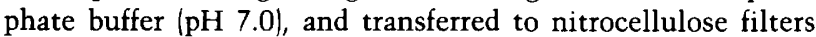
(Makmaster and Carmichael 1977; Thomas 1980). The filters were hybridized with appropriate probes as described by Thomas (1980).

\section{Materials}

Restriction enzymes were obtained from Takara Shuzo Co. (Kyoto). Radioactive nucleotides were purchased from Amersham.

\section{Acknowledgment}

We are grateful to Erik Rund for FACS analysis and to Ms. K. Hirano for preparation of the manuscript. This work was supported in part by grants for the Special Promotion of Science, and grant-in-aid from the Ministry of Education, Science and Culture of Japan and the Norwegian Cancer Society, Oslo, Norway.

\section{References}

Adachi, M., K. Okumura, N. Watanabe, N. Noro, T. Masuda, and J. Yodoi. 1985. Lack of Fc receptor for IgE in SJA 9 mice. Immunogenetics 22: 77-83.

Bech-Hansen, N.T., P.S. Linsley, and D.W. Cox. 1983. Restriction fragment length polymorphisms associated with immunoglobulin $\mathrm{C}_{\gamma}$ genes reveal linkage disequilibrium and genomic organization. Proc. Natl. Acad. Sci. 80: 6952-6956.

Chen, W.Y., C. Word, V. Dev, J. Uhr, S.E. Vitteta, and W.P. Tucker. 1986. Double isotype production by a neoplastic B cell line II. Allelically excluded production of $\mu$ and $\gamma 1$ heavy chains without $C_{\mathrm{H}}$ gene rearrangement. J. Exp. Med. 164: $562-579$.

Cory, S. and J.M. Adams. 1980. Deletions are associated with somatic rearrangements of immunoglobulin heavy chain genes. Cell 19: 37-51.

Flanagan, G.J., and J.H. Rabbitts. 1982. Arrangement of human immunoglobulin heavy chain constant regions implies evolutionary duplication of a segment containing $\gamma, \epsilon$, and $\alpha$ genes. Nature 300: 709-713.

Hisajima, H., Y. Nishida, S. Nakai, N. Takahashi, S. Ueda, and T. Honjo. 1983. Structure of the human immunoglobulin $C_{\epsilon 2}$ gene, a truncated pseudogene: Implications for its evolutionary origin. Proc. Natl. Acad. Sci. 80: 2995-2999.

Honjo, T., and T. Kataoka. 1978. Organization of immunoglobulin heavy chain genes and allelic deletion model. Proc. Natl. Acad. Sci. 75: 2140-2144.

Kataoka, T., T. Kawakami, N. Takahashi, and T. Honjo. 1980. Rearrangement of immunoglobulin $\gamma 1$-chain gene and mechanism for heavy-chain class switch. Proc. Natl. Acad. Sci. 77: 919-923.

Kataoka, T., T. Miyata, and T. Honjo. 1981. Repetitive sequences in class switch recombination regions of immunoglobulin heavy chain genes. Cell 23: 357-368.

Katona, I.M., J.F. Urban Jr., and F.D. Finkelman. 1985. B cells that simultaneously express surface $\operatorname{IgM}$ and $\operatorname{IgE}$ in Nippo- 
Kinashi et al.

strongylus brasiliensis-infected SJA/9 mice do not provide evidence for isotype switching without gene deletion. Proc. Natl. Acad. Sci. 82: 511-515.

Makmaster, G.K. and G.G. Carmichael. 1977. Analysis of single and double-stranded nucleic acids on polyacrylamide and agarose gels by using glyoxal and acridine orange. Proc. Natl. Acad. Sci. 74: 4835-4838.

Max, E.E., J. Battey, R. Ney, I.R. Kirsch, and P. Leder. 1982. Duplication and deletion in the human immunoglobulin $\epsilon$ genes. Cell 29: 691-699.

Nikaido, T., S. Nakai, and T. Honjo. 1981. Switch region of immunoglobulin $\mathrm{C}$ gene is composed of simple tandem repetitive sequence. Nature 292: 845-848.

Nishida, Y., T. Miki, H. Hisajima, and T. Honjo. 1982. Cloning of human immunoglobulin $\epsilon$ chain genes: Evidence for multiple $C_{\epsilon}$ genes. Proc. Natl. Acad. Sci. 79: 3833-3837.

Noma, Y., Y. Yaoita, N. Matsunami, A. Rośen, G. Klein, and T. Honjo. 1984. Immunoglobulin gene organization of UV-illuminated human lymphoblastoid cell lines producing both IgM and IgG. Mol. Biol. Med. 2: 337-350.

Perlmutter, A.P. and W. Gilbert. 1984. Antibodies of the secondary response can be expressed without switch recombination in normal B cells. Proc. Natl. Acad. Sci. 81: 71897193.

Rabbitts, J.H., A. Forster, W. Dunnick, and D.L. Bentley. 1980. The role of gene deletion in the immunoglobulin heavy chain switch. Nature 283: 351-356.

Southern, E.M. 1975. Detection of specific sequences among DNA fragments separated by gel electrophoresis. $1 . \mathrm{Mol}$. Biol. 98: 503-518.

Takahashi, N., S. Nakai, and T. Honjo. 1980. Cloning of human immunoglobulin $\mu$ gene and comparison with mouse $\mu$ gene. Nucleic Acids Res. 8: 5983-5991.

Takahashi, N., S. Ueda, M. Obata, T. Nikaido, S. Nakai, and T. Honjo. 1982. Structure of human immunoglobulin gamma genes: Implications for evolution of a gene family. Cell 29: $671-679$.

Thomas, P.S. 1980. Hybridization of denatured RNA and small DNA fragments transferred to nitrocellulose. Proc. Natl. Acad. Sci. 77: 5201-5205.

Ullrich, A., J. Shine, J. Chirguwin, R. Pictet, E. Tischer, W.J. Rutter, and H.M. Goodman. 1977. Rat insulin genes: Construction of plasmids containing the coding sequences. Science 196: 1313-1319.

Yaoita, Y., and T. Honjo. 1980a. Deletion of immunoglobulin heavy chain genes accompanies the class switch rearrangements. Biomed. Res. 1: 164-175.

$.1980 \mathrm{~b}$. Deletion of immunoglobulin heavy chain genes from expressed allelic chromosome. Nature 286: 850-853.

Yaoita, Y., Y. Kumagai, K. Okumura, and T. Honjo. 1982. Expression of lymphocyte surface IgE does not require switch recombination. Nature 297: 697-699. 


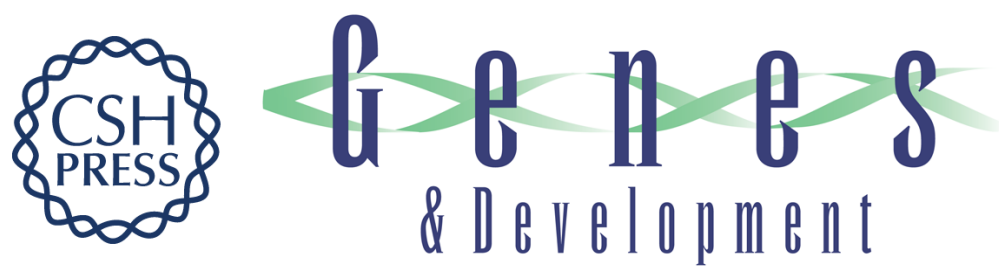

\section{Human neoplastic B cells express more than two isotypes of immunoglobulins without deletion of heavy-chain constant-region genes.}

T Kinashi, T Godal, Y Noma, et al.

Genes Dev. 1987, 1:

Access the most recent version at doi:10.1101/gad.1.5.465

References This article cites 25 articles, 11 of which can be accessed free at: http://genesdev.cshlp.org/content/1/5/465.full.html\#ref-list-1

License

Email Alerting

Receive free email alerts when new articles cite this article - sign up in the box at Service the top right corner of the article or click here.

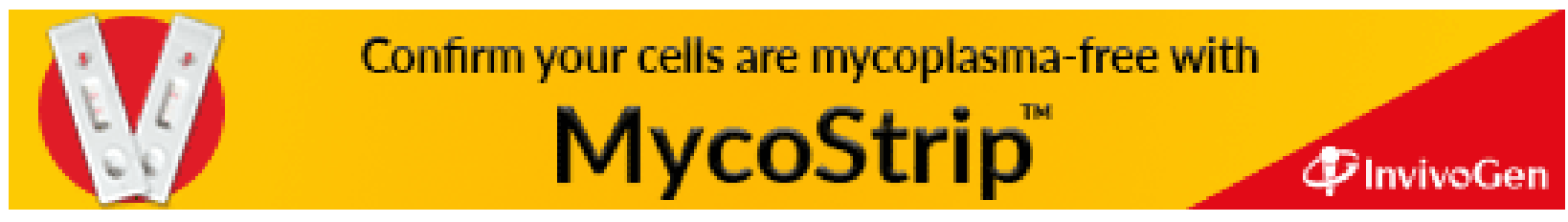

